\title{
Schizochytrium limacinum SR-21 as a source of docosahexaenoic acid: optimal growth and use as a dietary supplement for laying hens
}

\author{
H. J. Chin ${ }^{\mathrm{A}}$, T. F. Shen ${ }^{\mathrm{A}}$, H. P. Su${ }^{\mathrm{A}}$, and S. T. Ding ${ }^{\mathrm{A}, \mathrm{B}, \mathrm{C}}$ \\ ${ }^{A}$ Department of Animal Science and Technology, National Taiwan University, Taipei 106, Taiwan. \\ B 50, Lane 155, Kee-Long Rd, Sec 3, Taipei 106, Taiwan. \\ ${ }^{\mathrm{C}}$ Corresponding author. Email: sding@ntu.edu.tw
}

\begin{abstract}
Culture conditions for the marine fungus Schizochytrium limacinum SR-21 (SR-21) to produce microbial docosahexaenoic acid (DHA) were evaluated, and the practicality of using this fungus product as a dietary supplement for laying Leghorn hens was investigated. The data showed that the cultured fungus produced high biomass and DHA. It generated $584 \mathrm{mg} \mathrm{DHA} / \mathrm{L}$ of culture at the end of a 6-day culture. The fungus grew better at $25^{\circ} \mathrm{C}$ than at $20^{\circ} \mathrm{C}$ or $30^{\circ} \mathrm{C}$. With an increase in glucose concentration from $1 \%$ to $5 \%$ in the culture medium, biomass and DHA production were enhanced. A $6 \%$ glucose treatment reduced the biomass production compared with $5 \%$ glucose. A bioreactor was used to mass-produce SR-21. The biomass was increased from $1.12 \mathrm{~g} / \mathrm{L}$ at Day 0 to $12 \mathrm{~g} / \mathrm{L}$ at Day 4 . We established optimal culture conditions of $5 \%$ glucose, $2 \%$ sea salt, and $1 \%$ yeast extract for SR-21. Three concentrations of dried fungal meal $(0,1$, or $3 \%$ in the diet) were fed to birds over a 3 -week period. There were no negative effects of 1 and 3\% dietary SR-21 on egg production, egg weight, and egg yolk weight. The DHA content of yolk was increased by the dietary supplementation with the fungal meal both in the 1 and $3 \%$ treatments. Dietary fungal meal treatments increased the DHA concentrations of liver and plasma. However, dietary DHA enrichment had no effect on the expression of hepatic lipogenic genes in laying hens.
\end{abstract}

Additional keywords: laying Leghorn hens, lipid metabolism.

\section{Introduction}

Dietary $n-3$ polyunsaturated fatty acids (PUFA) such as linolenic acid, eicosapentaenoic acid (EPA), and docosahexaenoic acid (DHA) may help prevent coronary artery diseases, hypertension, diabetes, and inflammatory disorders (Innis 1992; Lewin et al. 2000; Simopoulos 2000). These beneficial effects of dietary $n$-3 PUFA on human health have stimulated interest in supplementation of animal feeds with dietary fish oil, fish meal, marine algae, linseed meal, or flaxseed meal to increase levels of $n$-3 PUFA (Navarro et al. 1972; Hargis et al. 1991; López-Ferrer et al. 2001).

The fatty acid (FA) profile of the egg yolk can be affected by the FA profile of the hen diets, particularly PUFA (Cruickshank 1934; Hargis et al. 1991; Cheng et al. 2004). Therefore, many researchers have tried to increase the levels of $n$-3 PUFA in egg yolk by dietary supplementation. By supplementing laying hen diets with $3-7 \%$ fish oil, it was possible to increase $n$-3 PUFA/egg to more than $200 \mathrm{mg}$ (Hargis et al. 1991). Eggs from hens fed $50 \mathrm{~g}$ fish oil $/ \mathrm{kg}$, contained significantly more DHA (5.27\% of total fatty acids) than ordinary eggs $(0.44 \%$ of total fatty acids; Farrell 1998$)$.

Although fish oil or fishmeal can be used to enrich the DHA content of egg yolk, fish odour is a concern with increasing amounts of dietary fish oil (Nash et al. 1995; de Swaaf et al. 1999). An inclusion of $6 \%$ fish oil in the diet has been reported to create a fishy flavour in $n$-3 PUFAenriched eggs (Adams et al. 1989). Similar flavour in hardcooked eggs from hens fed flaxseed meal was also reported (Scheideler and Froning 1996). Therefore, alternative $n-3$ PUFA sources are of interest, especially from marine algae and fungi that contain considerable amounts of EPA and DHA (Bajpai et al. 1992; Cohen 1994; Li and Ward 1994; Singh and Ward 1996; Chen and Vazhappilly 1998).

Schizochytrium limacinum SR-21 (SR-21) is a marine fungus isolated from the coral reef area of the Yap islands in the Federated States of Micronesia by Nakahara et al. (1996). The strain accumulates a high content of DHA and is a potential candidate for use as a DHA-rich ingredient in poultry diets (Nakahara et al. 1996; Yokochi et al. 1998). Recently, DHA-rich oil has been produced commercially from a similar microalga, Schizochytrium sp., and another strain, Crypthecodinium cohnii, by Martek Biosciences Co.

In the present study, culture conditions of SR-21 for producing maximal microbial DHA were evaluated. We also evaluated the use of the fungus as an alternative source of DHA in the diets for laying Leghorn hens to study the effect of dietary DHA enrichment on DHA accumulation in the egg. 


\section{Materials and methods}

\section{Microorganism and cell culture}

The SR-21 was obtained from the Institute for Fermentation, Osaka (IFO), Japan, strain number IFO 32693. The organism was platecultured with the GPY medium recommended by IFO, containing $20 \mathrm{~g}$ glucose, $10 \mathrm{~g}$ peptone, $5 \mathrm{~g}$ yeast extract, and $15 \mathrm{~g}$ agar in $1 \mathrm{~L}$ of $2 \%$ salinity artificial sea water (added sea salt $20 \mathrm{~g} / \mathrm{L}$, Sigma, St Louis, MO) at $25^{\circ} \mathrm{C}$. After 5 days of culture, an agar block $(1 \times 1 \mathrm{~cm})$ containing growing cells was cut from the plate and put into a $150-\mathrm{mL}$ Erlenmeyer flask containing $50 \mathrm{~mL}$ of a basal medium consisting of $2.0 \%$ glucose, $1.0 \%$ yeast extract, and $2.0 \%$ sea salt. The flask was incubated at $25^{\circ} \mathrm{C}$ on an orbital shaker set at $150 \mathrm{rpm}$ for 5 days, to produce an inoculum for further studies.

\section{Optimisation of biomass and DHA yield}

The effects of different culture conditions on cell biomass, lipid, and DHA yield for SR-21 were examined using batch cultures in 250-mL Erlenmeyer flasks using orbital shaking as described above. Each flask contained $150 \mathrm{~mL}$ medium and all cultures were inoculated with $5 \%(\mathrm{v} / \mathrm{v})(7.5 \mathrm{~mL})$ inoculum of cells from a culture grown in basal medium in shaken flasks for 5 days. Every experiment was repeated 3 times in the present study, unless indicated otherwise. Experimental conditions are described in detail in the relevant tables and figures.

\section{Determination of cell biomass}

Cells from each $250-\mathrm{mL}$ flask were harvested by centrifugation $(4000 \mathrm{G}$, $5 \mathrm{~min}$ ) with 2 washes with distilled water. The washed cell pellet was lyophilised until constant weight was achieved. The dry cell weight was the cell biomass yield for each sample.

\section{Lipid extraction and fatty acid analysis}

Lipids were extracted from $0.5 \mathrm{~g}$ lyophilised cells by using the method of Bligh and Dyer (1959) with 30 min sonication of the cells in $2: 1(\mathrm{v} / \mathrm{v})$ chloroform: methanol mixture. The extracted lipids were weighed and then converted to fatty acid methyl esters (FAMEs) to determine the fatty acid profile of the sample following the procedure described by Hsu et al. (2004). The FAMEs were extracted with n-hexane and then the fatty acid profile was determined by gas chromatography (model 263-30, Dani Educational, Italy) equipped with a $60 \mathrm{~m} * 0.53 \mathrm{~mm}$ ID, $1.00 \mu \mathrm{m}$ film thickness, Supelcowax-10 capillary column (Supelco Inc., USA) and a flame-ionisation detector. Nitrogen was used as the carrier gas. Initial column temperature was set at $120^{\circ} \mathrm{C}$, which was subsequently raised to $250^{\circ} \mathrm{C}$ at $5^{\circ} \mathrm{C} / \mathrm{min}$. The injector was kept at $250^{\circ} \mathrm{C}$ with an injection volume of $1 \mu \mathrm{L}$ under splitless mode. The detector temperature was set at $270^{\circ} \mathrm{C}$. Individual FA was identified by chromatographic comparison with authentic standards (Sigma, St Louis, MO) and the FA contents were quantified by comparing their peak areas with that of the internal standard (heptadecaenoic acid, C17:0).

\section{Animals and diets}

Fifteen 80-week-old white laying Leghorn hens (Hyline) of equal egg production were housed in individual cages with a light regimen of $16 \mathrm{~h}$ light: $8 \mathrm{~h}$ darkness. They were randomly divided into 3 groups. Diets were based on corn-soybean meal (ME, $2751 \mathrm{kcal} / \mathrm{kg}$; CP, 15.5\%; $\mathrm{Ca}, 3.4 \%$; Table 1) supplemented with $0,1.0$, or $3.0 \%$ of SR-21
Table 1. Composition of experimental diets

\begin{tabular}{|c|c|c|c|}
\hline Ingredients & Control & $\begin{array}{c}1 \% \text { Fungal } \\
\text { meal (\%) }\end{array}$ & $\begin{array}{c}3 \% \text { Fungal } \\
\text { meal }\end{array}$ \\
\hline Yellow corn & 62.47 & 62.47 & 62.47 \\
\hline Soybean meal & 23.16 & 23.16 & 23.16 \\
\hline Tallow & 1.8 & 1.5 & 0.9 \\
\hline Fungal meal & - & 1.0 & 3.0 \\
\hline Cellulose & 2.1 & 1.4 & - \\
\hline Dicalcium phosphate & 1.5 & 1.5 & 1.5 \\
\hline Limestone, pulverised & 8.0 & 8.0 & 8.0 \\
\hline Iodised salt & 0.3 & 0.3 & 0.3 \\
\hline Vitamin premix ${ }^{A}$ & 0.3 & 0.3 & 0.3 \\
\hline Mineral premix ${ }^{B}$ & 0.2 & 0.2 & 0.2 \\
\hline DL-Methionine & 0.17 & 0.17 & 0.17 \\
\hline Total & 100.00 & 100.00 & 100.00 \\
\hline Analysed lipid content (\%) & 10.5 & 10.6 & 10.6 \\
\hline Crude protein $(\%)$ & 15.50 & 15.50 & 15.50 \\
\hline $\mathrm{ME}(\mathrm{kcal} / \mathrm{kg})$ & 2751 & 2751 & 2751 \\
\hline Calcium (\%) & 3.4 & 3.4 & 3.4 \\
\hline
\end{tabular}

${ }^{\text {A }}$ Supplied per kg of diet: Vit. A, $11250 \mathrm{IU}$; Vit. $\mathrm{D}_{3}, 1200 \mathrm{IU}$; Vit. E, $37.5 \mathrm{IU}$; Vit. K, $2 \mathrm{mg}$; Vit. $\mathrm{B}_{1}, 2.6 \mathrm{mg}$; Vit. $\mathrm{B}_{2}, 8 \mathrm{mg}$; Vit. $\mathrm{B}_{6}, 3 \mathrm{mg}$; pantothenic acid, $15 \mathrm{mg}$; niacin, $60 \mathrm{mg}$; biotin, $0.2 \mathrm{mg}$; folic acid, $0.65 \mathrm{mg}$; Vit. $\mathrm{B}_{12}, 0.013 \mathrm{mg}$.

${ }^{\mathrm{B}}$ Supplied per kg of diet: $\mathrm{Cu}, 10 \mathrm{mg} ; \mathrm{Fe}, 100 \mathrm{mg}$; Mn, $60 \mathrm{mg}$; $\mathrm{Zn}, 65 \mathrm{mg}$; Se, $0.15 \mathrm{mg}$.

fungal meal. Vitamin E (37.5 IU/kg of diet) in the premix served as the antioxidant, and the diets were made up for the 3-week experimental period and stored in a $4{ }^{\circ} \mathrm{C}$ refrigerator to prevent lipid oxidation. The major fatty acids of the fungal meal were palmitic acid $(55.9 \%)$ and DHA $(32.7 \%)$ and the fatty acid profile is listed in Table 2 . The dietary FA composition is listed in Table 3. Feed and water were provided ad libitum. After feeding the hens with a control diet (containing $1.8 \%$ tallow) for 1 week to adapt to the experimental diet, the birds were fed with the experimental diets for 3 weeks. During the feeding period, eggs were collected every day and stored at $-20^{\circ} \mathrm{C}$ for further analysis. Egg production rate, egg weight, yolk weight, egg mass, and DHA concentration were measured on the 0,7 th, $14^{\text {th }}$, and 21 th day of feeding. At the end of the 3-week feeding period, the feed intake and feed conversion ratio ( $\mathrm{g}$ feed/g egg) were calculated. The blood samples were obtained from the brachial vein (V. Ulnaris) using EDTA as anticoagulant. After the hens were sacrificed by cervical dislocation, $3 \mathrm{~g}$ of liver tissue were obtained for determination of DHA concentration and the remaining liver sample was used for RNA extraction. Liver samples were removed, wrapped in foil, frozen in liquid nitrogen, and stored at $-70^{\circ} \mathrm{C}$. Egg yolk was freeze-dried for further analysis. Plasma, dry egg yolk, and diet samples were frozen at $-70^{\circ} \mathrm{C}$ until analysis of DHA concentration.

\section{RNA analysis}

Following the procedure described by Hsu and Ding (2003), total RNA was extracted from the powdered, frozen livers, separated by denatured electrophoresis, blotted to nylon membranes, and hybridised with radiolabelled cDNA probes in Ultrahyb solution (Ambion Inc., Austin, TX, USA). The duck genes of fatty acid synthase (FAS)

Table 2. Fatty acid composition (\% of total fatty acids) of Schizochytrium limacinum SR-21 fungal meal

\begin{tabular}{cccccccc}
\hline C16:0 & C16:1 & C18:0 & C18:1 & C18:2 (n-6) & C20:5 (n-3) & C22:5 (n-6) & C22:6 (n-3) \\
\hline 55.9 & 0.1 & 1.5 & 0.1 & 0.1 & 0.6 & 4.9 & 32.7 \\
\hline
\end{tabular}


Table 3. Fatty acid compositions of experimental diets expressed as percentage of total identified fatty acids

\begin{tabular}{lrcc}
\hline Fatty acid profile & Control & 1\% Fungal meal & 3\% Fungal meal \\
\hline C16:0 & 17.75 & 18.62 & 21.64 \\
C16:1 & 5.87 & 5.54 & 4.83 \\
C18:0 & 8.95 & 8.65 & 8.03 \\
C18: 1 & 36.66 & 36.02 & 31.40 \\
C18:2 $n-6$ & 24.99 & 23.91 & 23.83 \\
C18:3 $n-3$ & 4.43 & 3.77 & 3.59 \\
C20:4 $n-6$ & 1.37 & 1.39 & 1.42 \\
C20:5 $n-3$ & 0 & 0.02 & 0.08 \\
C22:6 $n-3$ & 0 & 2.13 & 5.28 \\
\hline
\end{tabular}

and lipogenesis-related transcriptional factors, sterol response element binding protein 1 (SREBP1) and SREBP2 (Yen et al. 2005), were used to generate probes for northern analysis of these genes. The FAS cDNA fragment is $490 \mathrm{bp}$ with $91 \%$ homology with the chicken FAS (GenBank, J04485). The SREBP1 cDNA fragment is 283 bp with 93\% homology with the chicken SREBP1 (GenBank, AJ310768). The SREBP 2 cDNA fragment is 386 bp with $83 \%$ homology with the chicken SREBP2 (GenBank, AJ310769). The primer sequences to generate the gene fragments are listed in Table 4 . The blots after hybridisation were quantified by phosphor-image analysis. The densitometric value for an individual transcript in a sample lane was normalised to the densitometric value for the 18S rRNA in the same lane.

\section{Statistical analysis}

Statistical analyses of experimental results were made using analysis of variance. Duncan's multiple range test was applied to detect differences among means using SAS statistical software (SAS Institute 2001). A probability level of 0.05 was used to show statistical significance.

\section{Results}

The cell growth (Table 5) increased as the concentration of glucose in the medium rose from $1 \%$ (biomass of $4.58 \mathrm{~g} / \mathrm{L}$ ) to $4.0 \%$ (biomass of $7.27 \mathrm{~g} / \mathrm{L}$ ), but the cell mass decreased at $5.0 \%$ and $6.0 \%$ glucose (biomass of 7.10 and $5.87 \mathrm{~g} / \mathrm{L}$ ). The lipid content of the biomass ranged from 28.79 to $45.84 \%$ in different treatment groups. The lipid yield varied from 1.32 to $3.26 \mathrm{~g} / \mathrm{L}$ for different treatments. Culture at $5.0 \%$ glucose resulted in the highest lipid yield. The DHA concentration of total fatty acids ranged from 27.42 to $28.38 \%$ for different treatments and there were no significant differences among treatments $(P>0.05)$. The DHA productivity increased as the glucose concentration in the medium rose from $1.0 \%(373 \mathrm{mg} / \mathrm{L})$ to $5.0 \%(874 \mathrm{mg} / \mathrm{L})$, and decreased with $6.0 \%$ glucose.

Because the SR-21 is a marine fungus, we investigated the effect of different concentrations of sea salt $(0-3.0 \%)$ on cell growth and DHA productivity. As shown in Table 6, $0 \%$ sea salt treatment generated the lowest biomass yield $(5.18 \mathrm{~g} / \mathrm{L})$, whereas the $1-3 \%$ treatments sustained much better cell growth that was not related to concentration. The lipid content in biomass among treatments ranged from 21.75 to $34.66 \%$. The 1 and $2 \%$ sea salt treatments resulted in a greater total lipid yield ( 3.33 and $3.10 \mathrm{~g} / \mathrm{L}$, respectively) than $0 \%$ sea salt. The DHA concentration of total fatty acids was not affected by sea salt concentration. However, numerically the maximal DHA productivity was obtained at $2.0 \%$ sea salt concentration.

The effects of initial culture $\mathrm{pH}$ on cell growth and DHA productivity were tested with the $\mathrm{pH}$ ranging from 5.0 to 8.0 (Fig. 1). Biomass yield and DHA productivity were not affected by initial $\mathrm{pH}(P>0.05)$. The biomass yield increased from $4.94 \mathrm{~g} / \mathrm{L}$ at 2 days to reach a plateau of $9.66 \mathrm{~g} / \mathrm{L}$ at 8 days, and then declined after 10 days of incubation $(8.75 \mathrm{~g} / \mathrm{L}$, Fig. 2$)$. The DHA productivity increased from 2 to 6 days, and then decreased from 6 to 10 days.

Table 4. Primers for FAS, transcription factors, SREBP1, and SREBP2

\begin{tabular}{llcc}
\hline Cloned gene & Sequence of primer & Size (bp) & Origin \\
\hline FAS & $\begin{array}{l}\text { Forward: 5'-ATTGACACAGCCTGCTCCTC-3' } \\
\text { Reverse: 5'-ACGGCTCTCTCTCACATTGG-3' }\end{array}$ & 490 & Goose \\
SREBP1 & $\begin{array}{l}\text { Forward: 5'-GCGCTACCGCTATCCATCA-3' } \\
\text { Reverse: 5'-GGTCGGCATCTCCATCACCT-3' }\end{array}$ & 283 & Chicken \\
SREBP2 & $\begin{array}{l}\text { Forward: 5'-TAATACGACTCACTATAGCG-3' } \\
\text { Reverse: 5'-TCAAGTCCTTCAGCCTCAAG-3' }\end{array}$ & 386 & Human \\
& & & \\
\hline
\end{tabular}

Table 5. Effect of glucose concentration on biomass yield (g/L), lipid content ( $\%$, d.w.), lipid yield (g/L), DHA content of total fatty acids $(\%)$ and DHA productivity $(\mathrm{mg} / \mathrm{L})$ of $S$. limacinum $\mathrm{SR}-21$

Culture condition: $25^{\circ} \mathrm{C}, 150 \mathrm{rpm}, 5$ days. Within columns, means followed by the same letter are not significantly different at $P=0.05$

\begin{tabular}{lccccc}
\hline Glucose conc. & Biomass yield & Lipid content & Lipid yield & DHA content & DHA productivity \\
\hline $1.0 \%$ & $4.58 \pm 0.45 \mathrm{~b}$ & $28.79 \pm 1.26 \mathrm{c}$ & $1.32 \pm 0.06 \mathrm{~d}$ & $28.27 \pm 1.27 \mathrm{a}$ & $373 \pm 17 \mathrm{c}$ \\
$2.0 \%$ & $6.19 \pm 0.19 \mathrm{a}$ & $39.91 \pm 2.90 \mathrm{ab}$ & $2.47 \pm 0.18 \mathrm{bc}$ & $27.89 \pm 2.49 \mathrm{a}$ & $688 \pm 61 \mathrm{~b}$ \\
$3.0 \%$ & $6.50 \pm 0.75 \mathrm{a}$ & $40.12 \pm 5.49 \mathrm{ab}$ & $2.61 \pm 0.36 \mathrm{~b}$ & $27.44 \pm 3.39 \mathrm{a}$ & $716 \pm 89 \mathrm{~b}$ \\
$4.0 \%$ & $7.27 \pm 0.26 \mathrm{a}$ & $41.28 \pm 1.44 \mathrm{ab}$ & $3.00 \pm 0.10 \mathrm{a}$ & $28.38 \pm 3.67 \mathrm{a}$ & $852 \pm 110 \mathrm{a}$ \\
$5.0 \%$ & $7.10 \pm 0.10 \mathrm{a}$ & $45.84 \pm 0.64 \mathrm{a}$ & $3.26 \pm 0.05 \mathrm{a}$ & $28.32 \pm 3.89 \mathrm{a}$ & $874 \pm 43 \mathrm{a}$ \\
$6.0 \%$ & $5.87 \pm 0.12 \mathrm{a}$ & $37.05 \pm 5.44 \mathrm{~b}$ & $2.18 \pm 0.32 \mathrm{c}$ & $27.42 \pm 1.48 \mathrm{a}$ & $602 \pm 29 \mathrm{~b}$ \\
\hline
\end{tabular}


Table 6. Effect of sea salt concentration on biomass yield (g/L), lipid content (\%, d.w.), lipid yield (g/L),

DHA concentration of total fatty acids $(\%)$, and DHA productivity $(\mathrm{mg} / \mathrm{L})$ of $S$. limacinum SR-21

Culture condition: $5 \%$ glucose, $1 \%$ yeast extract, $150 \mathrm{rpm}, 5$ days at $25^{\circ} \mathrm{C}$. Within columns, means followed by the same letter are not significantly different at $P=0.05$

\begin{tabular}{lrlrcc}
\hline Sea salt conc. & Biomass yield & \multicolumn{1}{c}{ Lipid content } & Lipid yield & DHA conc. & DHA productivity \\
\hline $0 \%$ & $5.18 \pm 0.91 \mathrm{~b}$ & $31.59 \pm 2.69 \mathrm{ab}$ & $1.47 \pm 0.12 \mathrm{~b}$ & $27.53 \pm 7.76 \mathrm{a}$ & $300 \pm 42 \mathrm{~b}$ \\
$1.0 \%$ & $9.90 \pm 1.12 \mathrm{a}$ & $34.66 \pm 2.16 \mathrm{a}$ & $3.33 \pm 0.63 \mathrm{a}$ & $27.69 \pm 6.51 \mathrm{a}$ & $413 \pm 18 \mathrm{ab}$ \\
$2.0 \%$ & $10.20 \pm 1.79 \mathrm{a}$ & $27.05 \pm 0.23 \mathrm{bc}$ & $3.10 \pm 0.01 \mathrm{a}$ & $35.18 \pm 0.46 \mathrm{a}$ & $447 \pm 20 \mathrm{a}$ \\
$3.0 \%$ & $10.89 \pm 0.78 \mathrm{a}$ & $21.75 \pm 0.07 \mathrm{c}$ & $2.48 \pm 0.05 \mathrm{ab}$ & $35.26 \pm 6.14 \mathrm{a}$ & $382 \pm 44 \mathrm{ab}$ \\
\hline
\end{tabular}

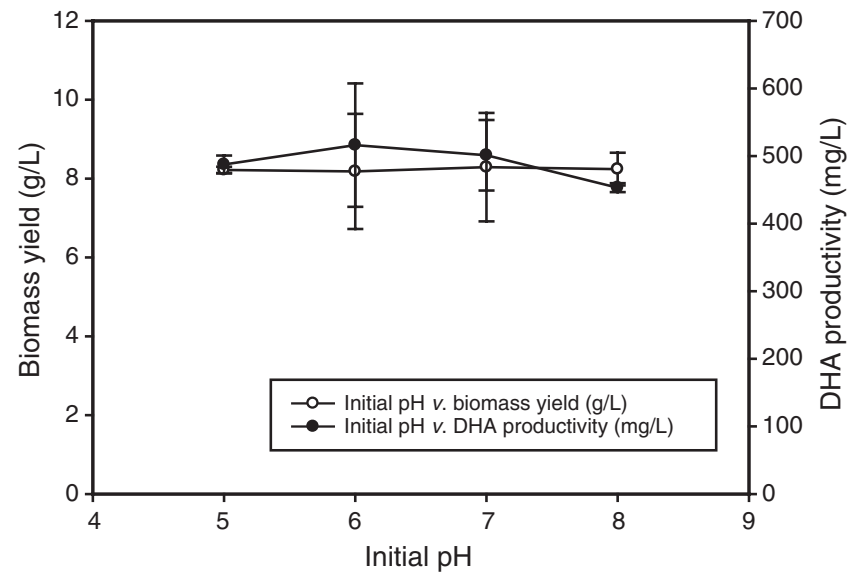

Fig. 1. Effects of the initial $\mathrm{pH}$ of the growth medium on biomass yield and docosahexaenoic acid (DHA) productivity of S. limacinum SR-21. The SR-21 was cultured in medium containing $5 \%$ glucose, $2 \%$ sea salt, and $1 \%$ yeast extract, for 5 days at $25^{\circ} \mathrm{C}$. The initial $\mathrm{pH}$ ranged from 5 to 8 .

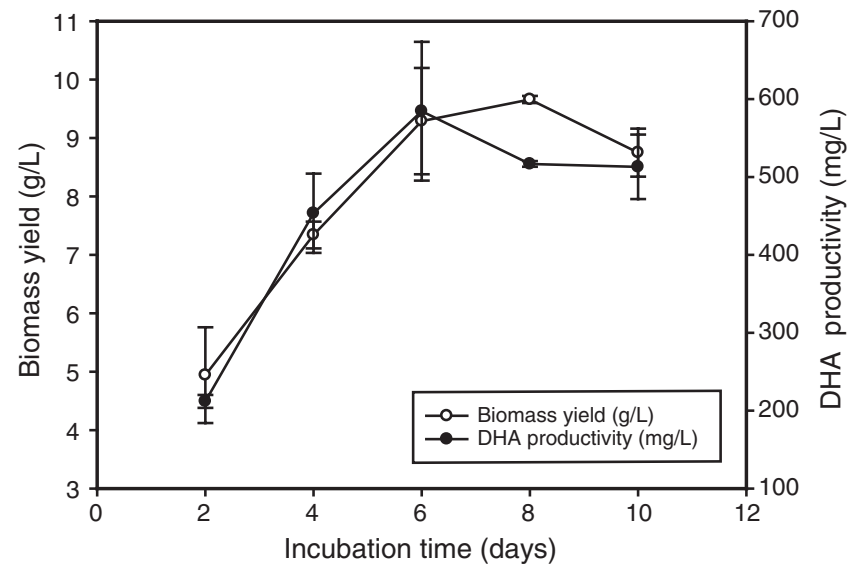

Fig. 2. Effects of the incubation time on biomass yield and docosahexaenoic acid (DHA) productivity of $S$. limacinum SR-21. The SR-21 was cultured in medium containing $5 \%$ glucose, $2 \%$ sea salt, $1 \%$ yeast extract, and with an initial $\mathrm{pH}$ of 6 and temperature at $25^{\circ} \mathrm{C}$. The cells were harvested every 2 days up to 10 days.
The maximal DHA productivity $(584 \mathrm{mg} / \mathrm{L})$ was obtained from the 6-day incubation.

Although the SR-21 when cultured at $20^{\circ} \mathrm{C}$ generated greater DHA concentration than cultured at other temperatures $\left(25^{\circ} \mathrm{C}\right.$ or $\left.30^{\circ} \mathrm{C}\right)$, the total biomass yield, lipid content in biomass, and overall DHA productivity were not significantly affected by temperature $(P>0.05$, Table 7$)$. After a 5-day incubation, the DHA productivity at $25^{\circ} \mathrm{C}$ was $601 \mathrm{mg} / \mathrm{L}$, whereas it was 552 and $468 \mathrm{mg} / \mathrm{L}$ for treatments of 20 and $30^{\circ} \mathrm{C}$, respectively.

The egg production, egg weight, yolk weight, egg mass, feed intake, and feed conversion ratio of the laying hens were not significantly affected by the fungal meal (containing $27 \%$ lipid and $33 \%$ of the total FA as DHA) supplementation in the diet $(P>0.05)$. During the experimental period, the egg production rate was $68-86 \%$, egg weights were $58.13-66.83 \mathrm{~g}$, and yolk weights were $15.86-18.02 \mathrm{~g}$ for different dietary treatments. The feed intake was $98-105$ (g/day), and the feed conversion ratio $(\mathrm{g} / \mathrm{g})$ was $2.19-2.35$ (feed/egg) for different dietary treatments. The egg mass was 46.8-53.4 g/hen.day for different dietary treatments.

The DHA concentrations of yolk, liver, and plasma were significantly increased by the dietary fungal meal supplementation $(P<0.05$, Tables 8,9$)$. The DHA concentrations in yolks were $0.36 \%, 1.17 \%$, and $1.81 \%$ of total fatty acids for $0 \%, 1 \%$, and $3 \%$ fungal meal treatments for 3 weeks, respectively (Table 8). The liver DHA concentrations of laying hens were $1.76 \%, 4.82 \%$, and $7.11 \%$ of total fatty acids for $0 \%, 1 \%$, and $3 \%$ fungal meal treatments $(P<0.05$; Table 9$)$.

The hepatic FAS, SREBP1, and SREBP2 mRNA concentrations were not affected by the 3 dietary treatments $(P>0.05$; Fig. 3). The hepatic lipogenesis-related genes of the laying hens were not affected by the dietary fungal meal supplementation.

\section{Discussion}

Several species that belong to the genus close to Thraustochytrium (Labyrinturomycota) have been shown to contain large quantities of DHA in their cytoplasm, and have been used as alternative sources for commercial DHA 
Table 7. Effect of culture temperature $\left({ }^{\circ} \mathrm{C}\right)$ on biomass yield (g/L), lipid content $(\%$, d.w.), lipid yield (g/L), DHA concentration of total fatty acids (\%) and DHA productivity $(\mathrm{mg} / \mathrm{L})$ of $S$. limacinum SR-21 Culture condition: $5 \%$ glucose, $1 \%$ yeast extract, and $150 \mathrm{rpm}$ for 5 days. Within columns, means followed by the same letter are not significantly different at $P=0.05$

\begin{tabular}{lrrrcc}
\hline Temp. & Biomass yield & Lipid content & Lipid yield & DHA conc. & DHA productivity \\
\hline 20 & $10.99 \pm 1.69 \mathrm{a}$ & $21.39 \pm 1.38 \mathrm{a}$ & $2.30 \pm 0.57 \mathrm{a}$ & $40.39 \pm 2.25 \mathrm{a}$ & $552 \pm 58 \mathrm{a}$ \\
25 & $12.23 \pm 0.80 \mathrm{a}$ & $25.84 \pm 0.64 \mathrm{a}$ & $3.13 \pm 0.17 \mathrm{a}$ & $24.28 \pm 1.83 \mathrm{~b}$ & $601 \pm 35 \mathrm{a}$ \\
30 & $8.73 \pm 1.71 \mathrm{a}$ & $19.84 \pm 1.09 \mathrm{a}$ & $1.67 \pm 0.48 \mathrm{a}$ & $23.22 \pm 2.37 \mathrm{~b}$ & $468 \pm 95 \mathrm{a}$ \\
\hline
\end{tabular}

Table 8. Effect of dietary S. limacinum SR-21 fungal meal on DHA levels of laying Leghorn hen egg yolk Values are means \pm s.d. of 5 eggs. Within columns, means followed by the same letter are not significantly different at $P=0.05$

\begin{tabular}{lcccr}
\hline Time & \multicolumn{4}{c}{$\%$ of total fatty acid } \\
& 0 Week & 1 Week & 2 Week & 3 Week \\
\hline Control & $0.42 \pm 0.12 \mathrm{a}$ & $0.37 \pm 0.10 \mathrm{~b}$ & $0.41 \pm 0.08 \mathrm{c}$ & $0.36 \pm 0.10 \mathrm{c}$ \\
$1.0 \%$ Fungal meal & $0.35 \pm 0.07 \mathrm{a}$ & $0.50 \pm 0.12 \mathrm{~b}$ & $1.03 \pm 0.24 \mathrm{~b}$ & $1.17 \pm 0.22 \mathrm{~b}$ \\
$3.0 \%$ Fungal meal & $0.40 \pm 0.12 \mathrm{a}$ & $1.08 \pm 0.18 \mathrm{a}$ & $1.74 \pm 0.12 \mathrm{a}$ & $1.81 \pm 0.26 \mathrm{a}$ \\
\hline
\end{tabular}

Table 9. Effect of dietary $S$. limacinum SR-21 fungal meal on DHA levels in the plasma and liver of laying Leghorn hens

Values are means \pm s.d. of 5 hens. Within columns, means followed by the same letter are not significantly different at $P=0.05$

\begin{tabular}{lcc}
\hline & \multicolumn{2}{c}{$\%$ of total fatty acids } \\
& Plasma & Liver \\
\hline Control & $1.02 \pm 0.09 \mathrm{c}$ & $1.76 \pm 0.17 \mathrm{c}$ \\
$1.0 \%$ Fungal meal & $4.41 \pm 0.93 \mathrm{~b}$ & $4.82 \pm 0.60 \mathrm{~b}$ \\
$3.0 \%$ Fungal meal & $7.26 \pm 1.24 \mathrm{a}$ & $7.11 \pm 1.19 \mathrm{a}$ \\
\hline
\end{tabular}

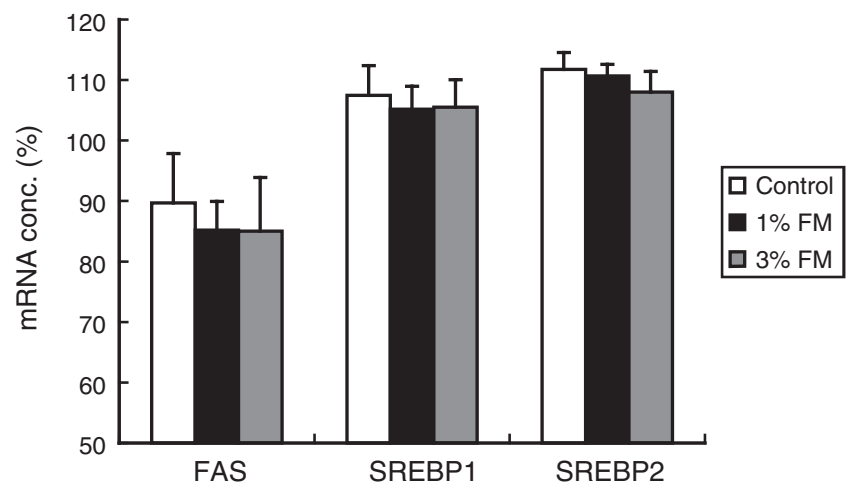

Fig. 3. The effect of dietary SR-21 fungal meal (FM) supplementation on the abundance of FAS, SREBP1, and SREBP2 mRNA in the livers of laying Leghorn hens. Leghorn hens were fed diets containing either $0 \%, 1 \%$, or $3 \%$ S. limacinum SR-21 fungal meal for 21 days (6 hens per group). On the day of sampling, hens were killed $2 \mathrm{~h}$ after feeding. The mRNA concentrations of FAS, SREBP1, and SREBP2, and concentration of $18 \mathrm{~S}$ rRNA were determined by Northern analysis. The mRNA values were normalised to $18 \mathrm{~S}$ rRNA content with $n=6$ replicates/treatment. There was no treatment effect detected $(P>0.05)$. production (Yongmanitchai and Ward 1992). In the present study, SR-21, a member of the Thraustochytrium family, also contained a high DHA concentration of about $30 \%$ of total fatty acids. Similar results were observed by Yokochi et al. (1998) who established standard culture conditions for S. limacinum SR-21. They found that about $30 \%$ of total FA was DHA when cultured with glucose, fructose, and glycerol. When cultured with these monosaccharides and glycerol as carbon sources, there was a greater dry cell weight than with di- or polysaccharides such as maltose and starch. Generally, excess energy sources in fungi culture will be metabolised to lipids (Evans and Ratledge 1984). Therefore, increasing the concentration of the carbon source will increase the lipid content in the culture medium. In the present study, the optimal glucose concentration for DHA production was $5.0 \%$. With $5.0 \%$ glucose, the DHA productivity reached a plateau at $874 \mathrm{mg} / \mathrm{L}$. Above $5.0 \%$ glucose, there was a reduction in culture biomass production, resulting in an overall decline in DHA productivity (Table 4). The high glucose concentration may create an inadequate osmotic pressure that represses cell growth. These results are not in agreement with the observations of Yokochi et al. (1998) who found that the maximal cell growth and DHA yield were obtained at $9 \%$ glucose. The discrepancy may due to different nitrogen sources and concentrations used in the 2 different experiments. In the present study, the nitrogen source was $1.0 \%$ yeast extract, whereas in Yokochi et al. (1998), it was $2.0 \%$ corn steep liquor.

Observations from Yokochi et al. (1998) showed that the SR-21 can tolerate a wide range of salinity. Although the fungus can grow at zero salinity, addition of $2 \%$ sea salt resulted in greater biomass and increased DHA productivity (Yokochi et al. 1998; Table 5). 
A range of initial $\mathrm{pH}$ from 5 to 8 in the culture medium did not have significant influence on the biomass yield or DHA productivity. The strain can grow well at a $\mathrm{pH}$ range of 5-8. Numerically, an initial pH of 6 was optimal for DHA production. An adequate initial $\mathrm{pH}$ in media for fungi or algae to produce EPA or DHA ranged from 6.0 to 7.6 (Bajpai et al. 1992; Yongmanitchai and Ward 1992). Li and Ward (1994) examined the DHA production of another marine fungus, Thraustochytrium roseum ATCC 28210, and found that an initial $\mathrm{pH}$ of 6.0 was optimal for maximum biomass and DHA production.

Moreton (1987) indicated that the major lipid accumulation in the cytoplasm of the cells was in the late-logarithmic growth phase and stationary phase, but not in the early logarithmic growth phase. In the current study, the logarithmic growth of strain SR-21 was observed within the first 6 days of incubation. Biomass yield in the medium reached the plateau after 8 days of cultivation and then decreased. The production of DHA increased in parallel with the cell growth and reached a plateau on the 6th day, and then decreased gradually.

The optimal temperature for growing SR-21 was found to be $25^{\circ} \mathrm{C}$ (Yokochi et al. 1998). We also found that this fungus grew well when cultured at $25^{\circ} \mathrm{C}$, and the DHA content of total FA was decreased when the culture temperature was increased. Other species, T. aureum and T. roseum, have the same optimal culture temperature of $25^{\circ} \mathrm{C}$ (Bajpai et al. 1991; Li and Ward 1994). Bowles et al. (1999) showed that Thraustochytrid species isolated from a subtropical mangrove produced higher levels of biomass, but the DHA fraction of the fatty acids was relatively lower than from SR-21 $(23.79 \%)$. Lower temperatures have been found to result in an increase in lipid unsaturation (Kates and Hagen 1964; Wassef 1977). Similar to what was found in the current study, the lower temperature resulted in lower biomass, but produced higher levels of DHA in the total fatty acids $(45.73 \%)$. Taken together, we suggest that the optimal culture conditions for SR21 are 5\% glucose, $1 \%$ yeast extract, and $2 \%$ sea salt with a $\mathrm{pH}$ of 6.0 and incubation for 6 days at $25^{\circ} \mathrm{C}$.

Fish oil has been used in the diet of laying hens to enrich the EPA or DHA content of eggs. We used the DHA-enriched fungus, SR-21, as a replacement for fish oil. This fungal meal enriched DHA in the egg yolk and also increased the DHA concentrations in livers and plasma of the laying hens. Several groups have indicated that egg production, egg weight, or yolk size was decreased by dietary PUFA (Whitehead et al. 1993; van-Elswyk et al. 1994; Scheideler et al. 1994), whereas other reports indicated no effect (Hargis et al. 1991; Ferrier et al. 1995; Meluzzi et al. 2000; Chen and Hsu 2003). We showed that egg production, egg weight, yolk size, and egg mass of the laying Leghorn hens were not affected by supplementation with 1 or $3 \%$ fungal meal in the diet for 3 weeks.
Nash et al. (1995) found that feeding laying hens diets containing $12 \%$ herring meal increased plasma DHA from $1.27 \%$ to $2.73 \%$ of total FA, or to $2.69 \%$ of total FA in another experiment. We observed (Table 9) a much greater increase (about 4- to 7-fold) of plasma DHA with dietary supplementations of 1 or 3\% SR-21 fungal meal for laying hens. Addition of $1 \%$ dietary menhaden oil for 3 weeks increased the yolk DHA content to $2.98 \%$ compared with $0.53 \%$ in the control group (Huang et al. 1990). Chen and Hsu (2003) found that incorporation of dietary DHA into egg yolk lipids reached a plateau after 2 weeks of feeding with fish-oil-containing diets. Therefore, an enrichment of dietary DHA will increase yolk DHA concentration. We also found that after 3 weeks of feeding with SR-21 fungal meal, the yolk DHA concentration was increased 5-fold compared with the control group. Perhaps a greater yolk DHA concentration could be achieved if we fed the hens with more than $3 \%$ fungal meal.

In the current study, the DHA concentration in the liver was increased after 3 weeks of feeding with fungal meal, confirming data in the literature (Huang et al. 1990; Leskanich and Noble 1997; López-Ferrer et al. 2001).

In poultry, liver is the major site for FA and cholesterol synthesis (Leveille et al. 1968, 1975). Two key enzymes involved in these processes are FAS and 3hydroxyl-3-methylglutaryl coenzyme A reductase (HMGCoA reductase), which are regulated by 2 transcription factors, SREBP1 and SREBP2, respectively (Back et al. 1986; Semenkovich 1997; Horton et al. 1998; Gondret et al. 2001). Recent researchers have shown that PUFA reduce the SREBP1 expression in rodent and pig livers (Xu et al. 1999; Yahagi et al. 1999; Hsu et al. 2004). Unlike the mammalian model, we did not find any effect of dietary DHA on the expression of the FAS gene or of these lipogenic transcription factors in the liver of the laying hens (Fig. 3). These findings are similar to what was reported by Cheng et al. (2004). Physiologically, the de novo lipogenesis in the liver of laying hens is high in order to generate yolk fat. Such cellular function may be related to a high oestrogen concentration, a factor that may induce fatty liver in aged laying hens (Harms et al. 1972; Polin and Wolford 1977; Dashti et al. 1983). Perhaps in the laying hens, the hormonal regulation is actively increasing lipogenesis and the hen is relatively unresponsive to dietary DHA content. Alternatively, the supplement levels of the fungal meal may not be high enough to affect the expression of these genes.

In conclusion, the present study demonstrates that dietary DHA-enriched fungal meal obtained from S. limacinum SR-21, can be digested and incorporated into eggs, plasma, and liver in the laying hens. Even though the expression of the FAS gene and the 2 transcription factors (SREBP1 and SREBP2) in the livers of laying hens was not affected by dietary DHA enrichments, the enrichment of yolk DHA may improve the value of the eggs for human consumption. 


\section{Acknowledgments}

This work was funded by the Council of Agriculture in Taiwan [Grant number 93AS-3.1.4-U1 (7)]. We thank Y. T. Kao for her technical assistance and Harry Mersmann for his input in enhancing this publication.

\section{References}

Adams RL, Pratt DE, Lin JH, Stadelman WJ (1989) Introduction of omega-3 polyunsaturated fatty acids into eggs. Poultry Science $\mathbf{6 8}$ (Suppl. 1), 166.

Back DW, Goldman MJ, Fisch JE, Ochs RS, Goodridge AG (1986) The fatty acid synthase gene in avian liver. Two mRNAs are expressed and regulated in parallel by feeding, primarily at the level of transcription. Journal of Biological Chemistry 261, 4190-4197.

Bajpai PK, Bajpai P, Ward OP (1991) Optimization of production of docosahexaenoic acid (DHA) by Thraustochytrium aureum ATCC 34304. Journal of the American Oil Chemists' Society 68 , 509-514.

Bajpai PK, Bajpai P, Ward OP (1992) Optimisation of culture conditions for production of eicosapentaenoic acid by Mortieralla elongata NRRL 5513. Journal of Industrial Microbiology 9, 11-18. doi: 10.1007/BF01576363

Bligh EG, Dyer WJ (1959) A rapid method of total lipid extraction and purification. Canadian Journal of Biochemistry and Physiology 37, 911-917.

Bowles RD, Hunt AE, Bremer GB, Duchars MG, Eaton RA (1999) Long-chain $n-3$ polyunsaturated fatty acid production by members of the marine protistan group the thraustochytrids: screening of isolates and optimisation of docosahexaenoic acid production. Journal of Biotechnology 70, 193-202. doi: 10.1016/S0168-1656(99)00072-3

Chen F, Vazhappilly R (1998) Eicosapentaenoic acid and docosahexaenoic acid production potential of microalgae and their heterotrophic growth. Journal of the American Oil Chemists' Society 75, 393-397.

Chen TF, Hsu JC (2003) Incorporation of $n$-3 long-chain polyunsaturated fatty acids into duck egg yolks. Asian-Australian Journal of Animal Science 16, 565-569.

Cheng CH, Shen TF, Chen WL, Ding ST (2004) Effect of dietary algal docosahexaenoic acid oil supplementation on fatty acid deposition and gene expression in laying Leghorn hens. Journal of Agricultural Science 142, 683-690.

Cohen Z (1994) Production potential of eicosapentaenoic acid by Monodus subterraneus. Journal of the American Oil Chemists' Society 71, 941-945.

Cruickshank EM (1934) Studies in fat metabolism in the fowl. 1. The composition of the egg fat and depot fat of the the fowl as affected by the ingestion of large amount of different fats. Biochemistry Journal 28, 965-977.

Dashti N, Kelly JL, Thayer RH, Ontko JA (1983) Concurrent inductions of avian hepatic lipogenesis, plasma lipids, and plasma apolipoprotein B by estrogen. Journal of Lipid Research 24, 368-379.

van-Elswyk ME, Hargis BM, Williams JD, Hargis PS (1994) Dietary menhaden oil contributes to hepatic lipidosis in laying hens. Poultry Science 73, 653-662.

Evans CT, Ratledge C (1984) Effect of nitrogen source on lipid accumulaction in oleaginous yeasts. Journal of General Microbiology 130, 1693-1704.

Farrell DJ (1998) Enrichment of hen eggs with $n$-3 long-chain fatty acids and evaluation of enriched eggs in humans. The American Journal of Clinical Nutrition 68, 538-544.
Ferrier LK, Caston LJ, Leeson S, Squires J, Weaver BJ, Holub BJ (1995) $\alpha$-Linolenic acid- and docosahexaenoic acid-enriched eggs from hens fed flaxseed: influence on blood lipids and platelet phospholipids fatty acids in humans. The American Journal of Clinical Nutrition 62, 81-86.

Gondret F, Ferre P, Dugail I (2001) ADD-1/SREBP-1 is a major determinant of tissue differential lipogenic capacity in mammalian and avian species. Journal of Lipid Research 42, 106-113.

Hargis PS, van Elswyk ME, Hargis BM (1991) Dietary modification of yolk lipid with menhaden oil. Poultry Science 70, 874-883.

Harms RH, Simpson CF, Damron BL (1972) Some new observations on 'fatty liver syndrome' in laying hens. Avian Diseases 16, 1042-1046.

Horton JD, Shimomura I, Brown MS, Hammer RE, Goldstein JL, Shimamo H (1998) Activation of cholesterol synthesis in preference to fatty acid synthesis in liver and adipose tissue of transgenic mice overproducing sterol regulatory element-binding protein-2. The Journal of Clinical Investigation 101, 2331-2339.

Hsu JM, Ding ST (2003) Effect of polyunsaturated fatty acids on the expression of transcription factor ADD1 and of lipogenic and fatty acid oxidation enzymes in porcine differentiating adipocytes. The British Journal of Nutrition 90, 507-513. doi: 10.1079/BJN2003918

Hsu JM, Wang PH, Liu BH, Ding ST (2004) The effect of dietary docosahexaenoic acid on the expression of porcine lipid metabolism related genes. Journal of Animal Science 83, 683-689.

Huang ZB, Leibovitz H, Lee MC, Millar R (1990) Effect of dietary fish oil on omega-3 fatty acid levels in chicken eggs and thigh flesh. Journal of Agricultural and Food Chemistry 38, 743-747. doi: $10.1021 / \mathrm{jf00093a034}$

Innis SM (1992) N-3 fatty acid requirments of the newborn. Lipids 27, 879-885.

Kates M, Hagen P-O (1964) Influence of temperature on fatty acids composition of psychrophilic and mesophilic Serratia species. Canadian Journal of Biochemistry and Physiology 42, 481-488.

Leskanich CO, Noble RC (1997) Manipulation of $n-3$ polyunsaturated fatty acid composition of avian eggs and meat. World's Poultry Science 53, 155-183. doi: 10.1079/WPS19970015

Leveille GA, O'Hea EK, Chkrabarty K (1968) In vivo lipogenesis in the domestic chicken. Proceedings of the Society for Experimental Biology and Medicine 128, 398-401.

Leveille GA, Romsos DR, Yen YY, O’Hea EK (1975) Lipid biosynthesis in the chick. A consideration of site of synthesis, influence of diet and possible regulatory mechanisms. Poultry Science 54, 1075-1093.

Lewin NM, Swburg S, Flanagan NL (2000) Enriched eggs as a source of $n$-3 polyunsaturated fatty acids for humans. Poultry Science 79, 971-974.

Li ZY, Ward OP (1994) Production of docosahexaenoic acid by Thraustochytrium roseum. Journal of Industrial Microbiology 13, 238-241. doi: 10.1007/BF01569755

López-Ferrer S, Baucells MD, Barroeta AC, Galobart J, Grashorn MA (2001) N-3 enrichment of chicken meat. 2. Use of precursors of long-chain polyunsaturated fatty acids: linseed oil. Poultry Science 80, 753-761.

Meluzzi A, Sirri F, Manfreda G, Tallarico N, Franchini A (2000) Effects of dietary vitamin $\mathrm{E}$ on the quality of table eggs enriched with $n-3$ long-chain fatty acids. Poultry Science 79, 539-545.

Moreton RS (1987) Physiology of lipid accumulating yeasts. In 'Single cell oil'. (Ed. RS Moreton) pp. 1-25. (Longman Scientific and Technical: Essex, UK)

Nakahara T, Yokochi T, Higashihara T, Tanaka S, Yaguchi T, Honda D (1996) Production of docosahexaenoic and docosapentaenoic acids by Schizochytrium sp. isolated from Yap Islands. Journal of the American Oil Chemists' Society 73, 1421-1426. 
Nash DM, Hamilton RMG, Hulan HW (1995) The effect of dietary herring meal on the omega-3 fatty acid content of plasma and egg yolk lipids of laying hens. Canadian Journal of Animal Science 75, 247-253.

Navarro JG, Saverder JC, Borie FB, Caiozzi MM (1972) Influence of dietary fish meal on egg fatty acid composition. Journal of the Science of Food and Agriculture 23, 1287-1292.

Polin D, Wolford JH (1977) Role of estrogen as a cause of fatty liver hemorrhagic syndrome. Journal of Nutrition 107, 873-886.

SAS Institute (2001) 'SAS user's guide: statistics.' (SAS Institute Inc.: Cary, NC)

Scheideler SE, Froning GW (1996) The combined influence of dietary flaxseed variety, level, form, and storage conditions on egg production and composition among vitamin E-supplemented hens. Poultry Science 75, 1221-1226.

Scheideler SE, Froning G, Cuppett S (1994) Effect of dietary flaxseed and fish oil on egg components, sensory analysis and oxidation products. Poultry Science 73 (Suppl. 1), 118.

Semenkovich CF (1997) Regulation of fatty acid synthase (FAS). Progress in Lipid Research 36, 43-53. doi: 10.1016/S01637827(97)00003-9

Simopoulos AP (2000) Human requirement for $n-3$ polyunsaturated fatty acids. Poultry Science 79, 961-970.

Singh A, Ward OP (1996) Production of high yields of docosahexaenoic acid by Thraustochytrium rosem ATCC 28210. Journal of Industrial Microbiology 16, 370-373. doi: 10.1007/BF01570118

de Swaaf ME, De Rijk TC, Eggink G, Sijtsma L (1999) Optimisation of docosahexaenoic acid production in batch cultivations by Crypthecodinium cohnii. Journal of Biotechnology 70, 185-192. doi: 10.1016/S0168-1656(99)00071-1
Wassef MK (1977) Fungal lipids. In 'Advances in lipids research'. (Eds A Paoletti, D Kritchevsky) pp. 15, 159-232. (Academic Press: New York)

Whitehead CC, Bowman AS, Griffin HD (1993) Regulation of plasma oestrogen by dietary fats in the laying hen: relationships with egg weight. British Poultry Science 34, 999-1010.

Xu J, Nakamura MT, Cho HP, Clarke SD (1999) Sterol regulatory element binding protein-1 expression is suppressed by dietary polyunsaturated fatty acids. Journal of Biological Chemistry 274, 23577-23583. doi: 10.1074/jbc.274.33.23577

Yahagi N, Shimano H, Hasty AH, Amemiya-Kudo M, Okazaki H, et al. (1999) A crucial role of sterol regulatory element binding protein-1 in the regulation of lipogenic gene expression by polyunsaturated fatty acids. Journal of Biological Chemistry 274, 35840-35844. doi: $10.1074 / \mathrm{jbc} .274 .50 .35840$

Yen CF, Jiang YN, Shen TF, Wong IM, Chen CC, Chen KC, Chang WC, Tsao YK, Ding ST (2005) Cloning and expression of the genes associated with lipid metabolism in Tsaiya ducks. Poultry Science 84, 67-74.

Yokochi T, Honda D, Higashihara T, Nakahara T (1998) Optimization of docosahexaenoic acid production by Schizochytrium limacinum SR21. Applied Microbiology and Biotechnology 49, 72-76. doi: $10.1007 / \mathrm{s} 002530051139$

Yongmanitchai W, Ward OP (1992) Growth and eicosapentaenoic acid production by Phaeodactylum tricornutum in batch and continuous culture systems. Journal of the American Oil Chemists' Society 69, 584-590.

Manuscript received 19 March 2005, accepted 7 September 2005 